\title{
The Effect of Organizational Culture on Employees Performance in Public Service Organization of Dire Dawa Administration
}

\author{
Aschalew Mulugeta ${ }^{1}$ \\ Ass. Professor of Management
}

\begin{abstract}
This study with the title of "The Effects of Organizational Culture on Employee Performance of public service organization of Dire Dawa administration" has an objective of testing whether organizational culture variables have a relation with employee job performance.This is a survey based research study. Primary and secondary data was used in this study. Primary data was gathered via questionnaire about employee performance and organizational culture variables like Employee participation, Openness to communication, Risk taking \& innovation, Customer service orientation, Reward system, level of education and experience are considered for this study. The target population of the study was all employees of three public service organization of Dire Dawa administration. Since the size of population was too large to collect data, researcher distributed 371 questionnaires randomly to respondents using the Yamane's sample size determination formula. Of which, 293 questionnaires were collected back and used for analysis. To analyze the data, in addition to descriptive statistics, multiple regressions was employed using a soft ware package SPSS 20.The researcher found that except experience and level of education all variables of organizational culture have contributed to employee job performance. Particularly employee participation and innovation have a significant contribution to employee job performance. Based on the finding, since communication has a negative significant relation with employee performance, researcher recommended public service organizations should be minimized communication platform to amplify employees job performance as well as develop reward system that motivate its employees. Finally, unless Dire Dawa administration design a new benefit package for public service employees in considering experience and level of education, they should not be focused on experience and level of education so as to increase employee's job performance and to provide quality service to the society.
\end{abstract}

DOI: $10.7176 / \mathrm{DCS} / 10-5-03$

Publication date:May $31^{\text {st }} 2020$

\section{INTRODUCTION}

This chapter deals with the background of the study, the basic problem statements, objective of the study, research hypothesis, significance of the study, delimitation and organization of the study.

\subsection{Background of the Study}

Every organization is influenced by the existing culture which varies from organization to organization. Corporate culture and reputation are intangible assets organizations use to create a competitive strategic advantage to differentiate themselves from other firms to enhance firm performance (Njugi Anne wanjiku, 2014 ). When you walk in different companies, one will experience a certain atmosphere, feeling, style personality, a charm, a feel that is unique to it, this as a result influences the way the employees relate to their clients.

Organizational development has certain factors that improve sustainability on basis of effectiveness. The improvement in productivity leads to employee commitment as norms, values and objectives helps in improving culture of an organization. The system of organization was based upon effective establishment of culture that keep learning environment strong. The performance of employees improves by establishment of strong culture of an organization.

The employee performance would be considered as backbone for organization as it leads to its development effectively. The loyalty of employee relies upon knowledge and awareness of culture that improves behavior of organization (Brooks, 2006). According to Kotter (2012) organizational culture has a direct impact on a variety of organizational variables. Research also shows that if employees are guided by the same norms and values in their organization, their performance would improve (Hofstede, 2007).

According to Magee (2002) organizational culture is the set of assumptions that members of an organization subscribe to. The assumptions are mainly beliefs and values. Beliefs focus on reality and they come from experience while values are about ideals that are desirable and worth striving for. It is the specific assortment of principles that are shared by everyone in the organization. This in turn controls the way these people intermingle with each other and with outsiders. The sharing of these beliefs and values create a business culture (Azhar, 2003). Robbins (2012) views organizational culture as a homogeneous discernment of the organization based on outstanding uniqueness separating one organization from the other.

\footnotetext{
${ }^{1}$ Asst professor of Management, RVU-DD campus
} 
A focus on organizational culture is increasingly becoming a major component of everyday organizational functioning because performance depends on its culture. A study culture within the organization shows that workers think the same way and are guided by the same ideas about the business (Racelis, 2010). Thus, organizations can only meet their goals if they make their culture work in harmony with their management coordination. By putting in place appropriate culture, an organization can allow the workers have control over their own work and this was no doubt make them work well. This is due to the fact that organizational performance is dependent upon the culture of the organization, since it is a clear indicator of the survival of the business (Racelis, 2010). The BSC average employee performance of most public service buroues perform around $60.2 \%$ and this performance is not upto the expectation of their respective bueroues. This may arise due to poor organizational culture in Dire Dawa Administration. This study therefore aims to assess the influence of Organizational Culture on Employee Performance of public service organizations in Dire Dawa Administration.

\subsection{Problem Statement}

The relationship between corporate culture and performance has been the subject of abundant research in several fields, including strategic management, organizational behavior, and industrial organizations. This study has been examined by many researchers (Kotter and Heskett 1992; Denison, 1990; Van der Post et al. 1998; Schwartz and Davis, 1981; Scholz,1987; Choe, 1993; Rashid and Anantharaman, 1997; Deshpande and Farley,1999; Ojo,2009). Despite the plethora of studies on organizational culture in the last few decades, there is no widely accepted causal relationship between organizational culture and performance in Ethipian contexist. The empirical evidence emerging from various studies about the effect of organizational culture on performance have so far yielded mixed results that are inconclusive and contradictory. Because of these contradictory results, the question of whether organizational culture improves or worsens employee performance is still worthy of further research.

The two years BSC average employee performance of the three buroue shows that most employees perform around $60.2 \%$. this record was an indicator to show the performance of most employees is not upto the expectation of their respective bueroues. this may arise due to lack of good organizational culture in their respective bueroues. Table 1.1: two years average employee performance

\begin{tabular}{|l|l|l|l|l|l|l|}
\hline No. & Name of Bueroues & \multicolumn{4}{|c|}{ Performance rank } \\
\cline { 3 - 7 } & & 795 & $80-95$ & $65-79$ & $50-64$ & $<50$ \\
\hline 1. & Education Bueroue & $5 \%$ & $34 \%$ & $56 \%$ & $5 \%$ & 0 \\
\hline 2. & Health Bueroue & $1 \%$ & $37 \%$ & $62 \%$ & 0 & 0 \\
\hline 3. & Agriculture Water and Energy Bueroue & $2 \%$ & $28 \%$ & $67 \%$ & $3 \%$ & 0 \\
\hline & Average & $\mathbf{2 . 7 \%}$ & $\mathbf{3 3 \%}$ & $\mathbf{6 0 . 2} \%$ & $\mathbf{2 . 6 7 \%}$ & $\mathbf{0}$ \\
\hline
\end{tabular}

Source:- summary of two years average performance report from the three bueroues

This study was intended to assess the influence of organizational culture on employee job performance of public service organizations in Dire Dawa Administration by raising the following research questions

1 What is the prevalence of organizational culture in public service organizations of Dire Dawa adminstration?

2 What is the extent or level of employees performance in public service organizations of Dire Dawa adminstration?

3 Hoe does the prevailing organizational culture affect employee performance in public public service organizations of Dire Dawa adminstration?

\subsection{General Objective}

Generally, the objective of this study was to assess the effect of organizstional culture on employee job performance of public service organization in Dire Dawa adminstration.

The specific objective of this study is to:-

- To assess the prevalence of organizational culture and its implication on employee performance in public service ogranization of Dire Dawa Adminstration

- To assess the extent or level of employee job performance in public service organizations of Dire Dawa A dminsration

- To assess how the prevailing organizational culture affect employee performance in public service organizations of Dire Dawa Adminstration

\subsection{Research Hypothesis}

Based on the above listed research questions and objectives the following hypothesis will be developed.

Hypothesis 1: Employee participation in the work place has a significant relation with employee's performance. Hypothesis 2: Openes to communication has a significant influence on employee's performance

Hypothesis 3: Risk taking and inovation capability of employee's has a significant relation with employee's 
performance.

Hypothesis4: The reward system of the organization has a significant influence on employee's performance Hypothesis5: Employee's customer service orientation in the work place has a significant influence on employee's performance

Hypothesis6: Employee's experience on the work place has a significant influence on employee's performance Hypothesis7: Employee's level of education has a significant influence on employee's performance

\section{Conceptual Framework}

Based on literature, certain parameters are taken to understand the impact of culture on the employee's job performance.

\section{Employee Participation}

In Schein's (1992), viewpoint participation of employees considered key element for setting organizational goals. As per theory setting goals, participation of employees can increase goals acceptance. According to Zairi (1999), a key attribute is participation, which is positively related to overall effectiveness of the organization. He also stated that participation is involved in delegating tasks as per the responsibilities of individual.

\section{Innovation and Risk-taking}

According to Kuhn (1985), Creativity means to produce something from nothing, whereas innovation makes a sense that something into the goods and services. According to Bucker (1997), innovation is consider an environment or a culture has almost a divine power, which exists in the organization and cause to drive value creation. Robbins, Stephen and Mary (1996), have identified three sets of variables that are responsible for stimulating innovation; Organization's structure, organizations culture and HR practices.

\section{Rewards system}

Bovee et al (1993), defines that theory of reinforcement described that the rewards should exploited to strengthen the appropriate behaviors and reinforces for undesirable things performance should be detached. Luthans (1998), states that organization should have the most up-to-date technology, well designed strategic plans, comprehensive job descriptions and inclusive training courses, but unfortunately, people are being rewarded based on performance- related behaviors of the employees, and there is a limited impact of technology, plans or rules. Bucker (1997) demonstrates that for reinforcing an organization's culture, organization's reward system considered a powerful tool.

\section{Openness of Communication}

Chester Barnard states that functions of the executives were; firstly, develop the thoughts of communication considered as a key shaping strength in organization (Luthans 1998). Good communication helps the employees to keep internal processes to run consistently and helpful to create superior association with the people, both within and outside the organization. According to the Luthans (1998), viewpoint, effective communication plays a very important role in industrial disagreements, miscommunication, gossips, and organizational divergences.

\section{Employee experiance}

According to Kate Le Gallez(2018), employee experience encapsulates all that people encounter, observe or feel over the course of their employee journey at an organization. employee experience is not static. In fact, it can vary from day to day. Because of this, it's useful to think about employee experience in terms of key milestones in the employee lifecycle. While all organizations are unique, they typically share these common experiences: candidates, onboarding, training, exiting, alumni. Each step in the employee lifecycle can be an important lever impacting both culture and performance. Asking for feedback at each key milestone helps organizations to understand how they're supporting their employees to be successful, and where they need to do more. (https://blog.cultureamp.com)

\section{Employee education}

Natalie Smith(2018), pointed out that Employee education is vital to the success of your firm it bolsters the value of the worker and develops their self-esteem so that they are able to contribute in a more meaningful way. A welldesigned professional development program contributes to employee motivation, engagement, and loyalty.

Employee education is one of the best ways to encourage their feelings toward contributing to the company, because people simply become more confident when they have more to offer. They can even use some of that knowledge in their personal lives which leads to both personal satisfaction and improved work morale (https://cultureiq.com). 


\section{Customer Service Orientation}

Joel and Michelle (2000), states that employees observe the organization's procedures as believing them well and giving wisdom of society at workplace and got the customers report regarding the quality of services. High service's quality could be resulted when the organizational culture communicates advanced customer service at the top.

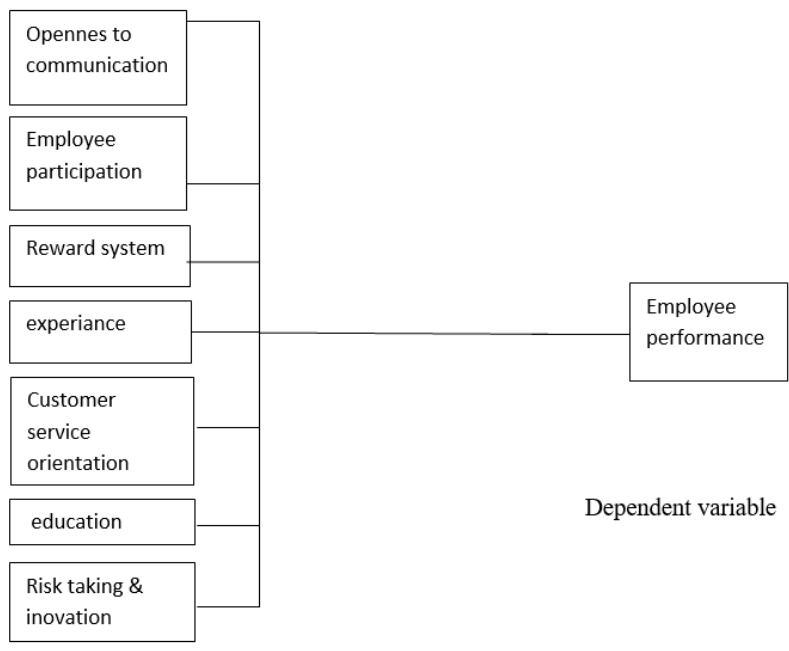

Element of independent variab

Figure 2.1: A conceptual framework of the current study

\section{CHAPTER THREE}

\section{RESEARCH METHODOLOGY}

In this section a through description of the research method for this study, the source of data, method of data collection, sampling method, and method of data analysis and interpretation was included.

\subsection{Research Design}

The research design is the conceptual structures within which research is conducted; it constitutes the blueprint for the collection, measurement and analysis of data (Selltiz, et.al, 1962). The study in order to determine the association, the degree of relationship between the independent variables (Employee participation, Risk taking \& inovation, Reward system, Customer service orientation, Opennes to communication experience and education) and the dependent variable (employee job performance) and to predict which variable has a significant influence on employee job performance of public service organizations of Dire Dawa Adminstration, used a correlational research design. According to Creswell (2008), Co relational research design is useful to researchers who are interested in determining to what degree two variables are related, and it indicates an association between two or more variablesll. The goal of correlational research is to establish whether relationships exist between selected variables. Correlational research is often presented as part of the descriptive family of methods. This makes sense since correlational research describes association between variables of interest in the study. It answers the question "what is in terms of relationship among two or more variables". Correlational research also includes the topics of linear and multiple regressions which uses the strengths of associations to make predictions.

\subsection{Method of Data Collection}

Primary data from the targeted source was collected using survey approach which is the most common data collection methods. Since it's difficult to analyze open ended questions using SPSS, only close ended questions with a five point likert scale type was employed.

\subsubsection{Instrument Design}

The questions was designed based on measure of employee job prformance and facets of organizational culture like Employee participation, Opennes to communication, Risk taking \& inovation, Customer service orientation and Reward system ,experience and education of employees.

Respondents was asked to indicate how much they agreed or disagreed with each statement using a five point likert scale with $1=$ fully disagree to $5=$ yes fully agree. Demographic question including experience, age, gender, qualification, specification and job title will placed at the beginning of the questionnaire. 


\subsection{Target Population}

The target population of the study comprised of the employees who are working within three bureaus of Dire Dawa adminstration that included education bureau, health bureau and agriculture water and energy bureau which means the total number of people from these three bureaus composed the target population of 5176 people. the main reason that the researcher focus on the above three bureau was that $63 \%$ of the total public service employees of DireDawa adminstration found on education, health, and agriculture water and energy bureau.

\subsection{Sampling Design}

\subsubsection{Sampling Technique}

According to Kothari (2009) sampling techniques are the instruments used in selecting the sample size. Therefore, this study employed stratified random sampling technique. Stratified random sampling was used since the population consists of public service employees who are working in three bueroues of DireDawa adminstration. In support of this Sarantokos (1998) stated that simple random sampling was employed to ensure that all employees stand equal chance of being selected to avoid sample bias and ensure that the results are reliable enough to be generalized.

According to Kothari (2009) stratified sampling is the method that involves dividing the population into different groups or classes. And these classes or categories are called strata and the sample is drawn from each stratum.

The researcher was employed this method in order to get the right number without bias when selecting the respondents from each stratum, in this regared each bureau will be considered as strata.

\subsubsection{Sample Size}

According to Kothari (2009) sample size is the number of items to be selected from the universe to constitute a sample but, the size of the sample to be drawn can be influenced by the size of the population and other parameters such as education, the nature of the research and the economic factor.

The respondents were the public service employees of the selected three bureau and their sample was examined by using the Yamane's theory to get the representative sample of the respondents from the target population as shown below:

$$
\mathrm{n}=\mathrm{N} /(1+\mathrm{N}(\mathrm{e}) 2
$$

Where $\mathrm{N}=$ Total number of employees from target population

$\mathrm{n}=$ Estimated sample size

$$
\mathrm{e}=\text { error of prediction/ detection }
$$

Therefore, $\mathrm{n}=5176 /(1+5176(0.05) 2$

$$
\mathrm{n}=371
$$

Therefore, ' $n$ ' represent the sample size of this study, which is 371.

The sample from each strata was computed by using a formula $=n \cdot P i / N$.

Where: $\mathrm{n}=$ represent the total sample size

$\mathrm{Pi}=$ represents the proportion of the population included in stratum $\mathrm{i}$.

$\mathrm{N}=$ Population drawn from or the target population.

Table 3.2: Sample of respondents

\begin{tabular}{|l|l|l|l|l|}
\hline No & Name of organization & Population & Samle size & Percentage \\
\hline 1 & Education bureau & 3299 & 236 & $7.15 \%$ \\
\hline 2 & Health bureau & 1543 & 111 & $7.19 \%$ \\
\hline 3 & Agriculture water and energy bureau & 334 & 24 & $7.18 \%$ \\
\hline & Total & 5176 & 371 & $7.17 \%$ \\
\hline
\end{tabular}

\subsection{Methods of Data Analysis}

The analysis of the data enables to examine the relationships between dependent and independent variables. In addition, it shows which set of independent variables would predict the best outcome for dependent variable.

The dependent variable of the study was employees job performance. The element of employee job performance was used as a single item measurement. Wonous, Reichers and hudy (1997, pp: 247-252) argue that single item measures can be acceptable measure of job performance.

The independent variable of the study was organizational culture. organizational culture was measured by constructing question based on the facets of organizational culture as put forward by (Fakhar Shahzad et.al ,2013). These facets are Employee participation, Opennes to communication, Risk taking \& inovation, Customer service orientation, Reward system, experience, and education. In order to analyze the data obtained from the questionnaires the statistical program SPSS 20 was used.

\subsubsection{Reliability Analysis}

The internal reliability and validity is important as it helps ascertain whether each scale is measuring a single idea 
and whether all the items with that scale are internally consistent. In support of this Morgan etal (2007: p.129) stated that the reliability of a measure refers to its consistency and often entails the external and internal aspect of reliability with multiple item scales. Thus, to ensure that the measures of items of organiuzational culture was internally reliable, a reliability analysis was employed in Dire Dawa A dminstration center of competency office to check the internal consistency of the scale. In order to achieve this, the following mathematical formula for Cronbaches alpha was used to measure the reliability and internal consistency.

$$
R=\left[\frac{k c}{v+(k-1) c}\right]
$$

Where: $-K=$ is the number of test items

$\mathrm{v}=$ is the average variance, and

$\mathrm{c}=$ is the average of all covariance between the components across the current sample.

\subsubsection{Statistical Analysis}

Statistical analysis was employed to examine the relationships among study variables and to test whether those independent variables have a positive relationship on dependent variable.

In order to achieve the purpose, both descriptive statistics (mean and percentage) and inferential statistics (multiple regressions) was employed. Morgan et.al (2007,p.134) and (Argyrous George, 2005 P: 189) state that multiple regression usually investigate the relationship between a dependent variable and several independent variables. Multiple regressions explore relationships between one dependent variable and a number of independent variable. Multiple regressions can be used not only to assess the relationship between these variables but also which organizational culture facets predicted the most likely impact on employee job performance.

\subsubsection{Model Specification}

The functional specification for multiple linear regression model deals where response $\mathrm{Y}$ is related to a set of qualitative independent variables. The general lineal model has the following structure (Ott, 2001):

$$
\mathbf{Y}=\mathbf{B}_{\mathbf{0}}+\mathbf{B}_{\mathbf{1}} \mathbf{x} \mathbf{1}+\mathbf{B}_{2} \mathbf{x}_{2}+\ldots \ldots \ldots . . .+\mathbf{B K X}_{\mathbf{X}} \mathbf{X}+\boldsymbol{\xi}
$$

Then, the main relationships $\mathrm{b} / \mathrm{n}$ dependent and independent variables can be seen below:

$$
\begin{aligned}
& \mathbf{Y}=\beta_{0}+\beta_{1} x_{1}+\beta_{2} x_{2}+\beta_{3} \times 3+\beta_{4} \times 4+\beta_{5} \times 5 \beta_{6} \times 6+\beta_{7} \times 7+\beta_{8} \times 8+e \\
& \text { Where: } Y=\text { is employee performance } \\
& \beta 0=\text { is the } Y \text { intercept when } x \text { is zero }
\end{aligned}
$$

$\beta_{1}, \beta_{2}, b_{3}, \beta_{4}$ and $\beta_{5}$ are regression weights attached to the variables;

$\boldsymbol{X}_{\boldsymbol{l}}=$ Employee participation; $\boldsymbol{X}_{\mathbf{2}}=$ Opennes to communication; $\boldsymbol{X}_{\mathbf{3}}=$ Risk taking \& inovation,; $\boldsymbol{X}_{\mathbf{4}}=$ Customer service orientation; $\boldsymbol{X}_{\mathbf{5}}=$ Reward system; $\boldsymbol{X}_{\boldsymbol{6}}=$ experience; $\boldsymbol{X}_{7}=$ education $\boldsymbol{e}=$ error term

\subsection{Ethical Considerations}

All parts of a research project - from the project design to submission of the results for peer review - have to be upstanding in order to be considered ethical. When even one part of a research project is questionable or conducted unethically, the integrity of the entire project is called into question ((Bryman and Bell, 2003).

Regarding the ethics of a research the researcher; asked the consent of participants to respond to the questionnaires voluntarily, worked hard to contribute to the good of the society, didn't fabricate or falsify data, research procedure or data analysis; respected the rights of research subjects, particularly their rights to information privacy, and informed about the nature of the research.

Moreover, a researcher didn't pass off somebody else's ideas, thoughts, theories, words, or stories as a researchers own work (plagiarism), acknowledged the substantive contributions of all research participants, whether colleagues or students, according to their intellectual contribution, kept the confidentiality of participants and used only and only for the research purpose.

\section{Results and Discussion}

\subsection{Descriptive Statistics and Analysis}

In this section a summary of the empirical findings derived from the questionnaire is presented. The detailed demographic data and individual questions responses have been shown in the following tables. The data has been categorized into three parts. These are demographic data, organizastional culture data and employee performance data.

\subsubsection{Demographic characteristics of the population}

Since the general characteristics of the respondents are vital to get insights to the overall study, the researcher starts by presenting the demographic nature of the respondents. The researcher analyzed the collected demographic data using a descriptive statistics (Frequency statistics and Percentage). 
Table 4.2: Demographic Characteristics of Respondents

\begin{tabular}{|l|l|c|c|}
\hline Demographic Variables & \multicolumn{1}{|c|}{ Category } & Frequency & Valid Percentage (\%) \\
\hline \multirow{4}{*}{ Agender } & Male & 175 & 59.7 \\
\cline { 2 - 4 } & Female & 116 & 39.6 \\
\hline \multirow{5}{*}{ Length of service } & $18-25$ & 11 & 3.8 \\
\cline { 2 - 4 } & $26-35$ & 120 & 41.0 \\
\cline { 2 - 4 } & $36-45$ & 81 & 27.6 \\
\cline { 2 - 4 } & $46-55$ & 46 & 15.7 \\
\cline { 2 - 4 } & Above 55 & 35 & 11.9 \\
\hline \multirow{5}{*}{ Job position in the organization } & Less than-1 years & 19 & 6.5 \\
\cline { 2 - 4 } & $1-5$ years & 91 & 31.1 \\
\cline { 2 - 4 } & $6-10$ years & 79 & 27.0 \\
\cline { 2 - 4 } & Above 10 years & 102 & 34.8 \\
\cline { 2 - 4 } & Top Manager & 8 & 2.7 \\
\cline { 2 - 4 } & Middle managere & 47 & 16.0 \\
\cline { 2 - 4 } & Lower manager & 80 & 27.3 \\
\cline { 2 - 4 } & Staff & 158 & 53.9 \\
\hline Education & Certificate & 3 & 1.0 \\
\cline { 2 - 4 } & Diploma & 39 & 13.3 \\
\cline { 2 - 4 } & Degree & 189 & 64.5 \\
\cline { 2 - 4 } & Masters \& above & 57 & 19.5 \\
\hline
\end{tabular}

4.1.2. Descriptive Statistics: Organizational Culture

The twenty-seven (27) items used to measure organizational culture were categorized into five components. these are customer service orientation, opennes to communication, employee participation, risk taking and innovation and reward systems. The mean and standard deviation of each component presented as follow.

4.1.2.1. Customer Service Orientation

Table 4.3: Means and Standard Deviations for customer service orientation

Descriptive statistics

\begin{tabular}{|c|c|c|c|}
\hline Statements & $\mathrm{N}$ & Mean & Std. Deviation \\
\hline Every effort is made to deliver to customers on time & 293 & 2.3686 & .71718 \\
\hline customers' problems are recognized and dealt with promptly & 293 & 2.5427 & .76462 \\
\hline follow-ups made to ensure that customers happy with the service & 293 & 2.7338 & .83427 \\
\hline customers are considered as part of the organization & 293 & 2.6280 & 1.46237 \\
\hline Valid N (listwise) & 293 & & \\
\hline
\end{tabular}

4.1.2.2. Openness to Communication

Table 4.4: Means and Standard Deviations for opennes to communication

\begin{tabular}{|c|c|c|c|}
\hline Statements & $\mathrm{N}$ & Mean & Std. Deviation \\
\hline I can talk freely with my manager & 293 & 2.5427 & 1.97303 \\
\hline The management discuss issues and ideas with the employees & 293 & 2.7167 & .87876 \\
\hline I see my manager whenever I need to & 293 & 3.0341 & .86337 \\
\hline Communication seems good within the organization & 293 & 2.6621 & .84713 \\
\hline Discussion at meetings is very free and open & 293 & 2.6792 & 2.45497 \\
\hline Managers and staff have informal discussions & 293 & 2.7372 & .86159 \\
\hline management keep as informed about issues in the organization & 293 & 2.8294 & .75277 \\
\hline Valid N (listwise) & 293 & & \\
\hline
\end{tabular}

4.1.2.3. Employee Participation

Table 4.5: Means and Standard Deviations for employee participation

\begin{tabular}{|c|c|c|c|}
\hline Statements & $\mathrm{N}$ & Mean & Std. Deviation \\
\hline consider everyone's views before a decision is made & 293 & 2.9078 & .80774 \\
\hline Employees are asked for their suggestions & 293 & 2.6894 & .84953 \\
\hline My job is recognized as valuable by the organization & 293 & 2.6485 & .82510 \\
\hline Our managers express interest in our ideas & 293 & 2.7884 & .76945 \\
\hline I am involved in decision affecting my job & 293 & 2.7474 & .81365 \\
\hline Valid N (listwise) & 293 & & \\
\hline
\end{tabular}


4.1.2.4. Risk Taking and Innovation

Table 4.6: Means and Standard Deviations for risk taking and innovation

\begin{tabular}{|l|r|r|r|}
\hline \multicolumn{1}{|c|}{ Statements } & N & Mean & Std. Deviation \\
\hline My organization is risk taking & 293 & 2.8601 & .87832 \\
Radical ideas are utilized by the management & 293 & 2.7679 & .80711 \\
management consider others opinion before making decision & 293 & 2.7918 & .76369 \\
Funds are available for trying out new ideas & 293 & 3.0000 & .92529 \\
Time is made available to explore and develop new ideas & 293 & 2.9181 & .78084 \\
There is a minimum of red tape when it comes to new ideas & 293 & 2.7918 & .74554 \\
Valid N (listwise) & 293 & & \\
\hline
\end{tabular}

4.1.2.5. Reward System

Table 4.7: Means and Standard Deviations for reward system

\begin{tabular}{|l|r|r|r|}
\hline \multicolumn{1}{|c|}{ Statements } & \multicolumn{1}{|c|}{ N } & Mean & Std. Deviation \\
\hline Employees are rewarded according to their performance & 293 & 3.0580 & .92901 \\
Reward is provided based on achievement of result & 293 & 3.1297 & .90862 \\
reward you receive the cause for your job performance improvement & 293 & 3.0648 & .96473 \\
you are fairly rewarded in r/n to your salary for the work you perform & 293 & 3.1331 & .93231 \\
you are fairly rewarded in r/n to responsibilities you have in your job & 293 & 3.1433 & .92525 \\
you are fairly rewarded in r/n to your colleagues receive for the same job & 293 & 3.1331 & .90245 \\
Valid N (listwise) & 293 & & \\
\hline
\end{tabular}

\subsection{Descriptive Statistics: employee performance}

Table 4.7: Means and Standard Deviations for employee performance

\begin{tabular}{|l|r|r|r|}
\hline \multicolumn{1}{|c|}{ Statements } & \multicolumn{1}{|c|}{$\mathrm{N}$} & Mean & Std. Deviation \\
\hline Employees of the organization complete work on time & 293 & 2.6826 & .80555 \\
Employees are committed to improving quality of services & 293 & 2.7645 & .69919 \\
Employees are committed to the success of the company & 293 & 2.8055 & 1.36481 \\
Employees are committed to serving the company & 293 & 2.7270 & .75434 \\
Employees are held accountable for their work & 293 & 2.6212 & .79586 \\
The organization is able to maximize employee potential & 293 & 2.7918 & .84865 \\
Employees' job enable them to make use of their skills and abilities & 293 & 2.6724 & .77757 \\
Employees get a sense of personal accomplishment from work & 293 & 2.6997 & .74386 \\
Employee are willing to bear the risk of faulty work & 293 & 2.6997 & .80998 \\
Employees show creativity to increase performance, by initiating new & 293 & 2.7167 & .74826 \\
Performance measures are evaluated on an annual basis & 293 & 2.6416 & .86280 \\
Employees know and understand the needs of customers & 293 & 2.6382 & .86731 \\
Employees are able to meet annual work targets and goals assigned & 293 & 2.6655 & .80500 \\
Employees are reliable when it comes to execution of tasks at work & 293 & 2.6792 & .70673 \\
Employees always look for new ways of executing their task & 293 & 2.7986 & .80478 \\
Employees have frequent feedback on their personal performance & 291 & 3.1306 & 2.47821 \\
Valid N (listwise) & 291 & & \\
\hline
\end{tabular}




\subsection{Multiple Regression Analysis}

\section{Model Summary ${ }^{b}$}

\begin{tabular}{|l|r|r|r|r|}
\hline Model & R & R Square & Adjusted R Square & Std. Error of the Estimate \\
\hline 1 & $.811^{\mathrm{a}}$ & .779 & .760 & .67196 \\
\hline
\end{tabular}

a. Predictors: (Constant), reward system, openness to communication, risk taking $\&$ innovation, customer service orientation, employee participation, experience, education.

b. Dependent Variable: employee performance

\begin{tabular}{|rl|r|r|r|r|r|}
\hline Model & & SNOVA & \\
a & Sum of Squares & Df & Mean Square & \multicolumn{1}{c|}{ F } & Sig. \\
\hline \multirow{2}{*}{1} & Regression & 13.161 & 5 & 2.632 & 5.830 & $.000^{\mathrm{b}}$ \\
& Residual & 129.590 & 287 & .452 & & \\
& Total & 142.751 & 292 & & & \\
\hline
\end{tabular}

a. Dependent Variable: employee performance

b. Predictors: (Constant), reward system, openness to communication, risk taking \& innovation, customer service orientation, employee participation, experience, education.

\subsubsection{Evaluating Contribution of Independent Variables on dependent variable.}

Coefficients ${ }^{\mathrm{a}}$

\begin{tabular}{|c|c|c|c|c|c|c|c|c|}
\hline \multirow{2}{*}{\multicolumn{2}{|c|}{ Model }} & \multicolumn{2}{|c|}{$\begin{array}{l}\text { Unstandardized } \\
\text { Coefficients }\end{array}$} & $\begin{array}{c}\text { Standardized } \\
\text { Coefficients }\end{array}$ & \multirow[t]{2}{*}{$\mathrm{T}$} & \multirow[t]{2}{*}{ Sig. } & \multicolumn{2}{|c|}{ Collinearity Statistics } \\
\hline & & $\mathrm{B}$ & $\begin{array}{l}\text { Std. } \\
\text { Error }\end{array}$ & Beta & & & Tolerance & VIF \\
\hline \multirow{8}{*}{1} & (Constant) & 1.337 & .234 & & 5.721 & .000 & & \\
\hline & customer service & .111 & .053 & .122 & 2.090 & .038 & .830 & 1.205 \\
\hline & communication & -.150 & .047 & -.188 & -3.168 & .002 & .793 & 1.261 \\
\hline & participation & .241 & .054 & .265 & 4.459 & .000 & .794 & 1.259 \\
\hline & Innovation & .161 & .051 & .186 & 3.179 & .002 & .820 & 1.220 \\
\hline & Reward & .103 & .044 & .136 & 2.320 & .021 & .812 & 1.231 \\
\hline & Experience & .048 & .038 & .068 & 1.259 & .209 & .959 & 1.043 \\
\hline & Education & -.006 & .009 & -.038 & -.705 & .482 & .959 & 1.043 \\
\hline
\end{tabular}

The values for the regression weights are as follows:

$\mathrm{Y}=\mathbf{1 . 3 3 7}+\mathbf{0 . 2 4 1} \times 1+\mathbf{- 0 . 1 5 0} \times 2+\mathbf{0 . 1 6 1} \times 3+0.111 \times 4+\mathbf{0 . 1 0 3} \times 5+\mathbf{0 . 0 4 8} \times 6+\mathbf{- 0 . 0 0 6} \times 7+\mathrm{e}$

Where:Y $=$ is employee performance

$\boldsymbol{X} \boldsymbol{l}=$ Employee participation;

$\boldsymbol{X}_{\mathbf{2}}=$ Opennes to communication;

$\boldsymbol{X}_{\mathbf{3}}=$ Risk taking \& inovation,;

$\boldsymbol{X}_{\mathbf{4}}=$ Customer service orientation;

$\boldsymbol{X}_{\mathbf{5}}=$ Reward system;

$\boldsymbol{X}_{\mathbf{6}}=$ experience;

$X_{7}=$ education

$e=$ error term

\subsection{Hypotheses Test}

In order to measure the significant influence of independent variables on the dependent variable and to test the proposed hypotheses the researcher employed multiple regression analysis. By looking at the Sig.-value in table 4.13 it is possible to interpret whether the particular independent variable has a significant influence on the dependent variables. The rules of thumb for this study was used, if Sig. $<\mathrm{a}=.05, \mathrm{H} 0$ rejected, and conversely, if Sig. $>\mathrm{a}=.05, \mathrm{H} 0$ was not reject. Hypothesis is supported when the Sig. value is smaller than 0.05; and a null hypothesis is rejected when the Sig. value is equal or larger than 0.05 (Pallant, 2010).

Hypothesis 1: Employee participation in the work place has a significant relation with employee's performance.

Null hypothesis: Ho: $\mathrm{r}=0$

Alternative hypothesis: $\mathrm{H} 1: \mathrm{r} \neq 0$

As indicated in the regression table, the $p$-value for Employee participation was $(p=0.000)$ and the corresponding beta coefficient indicated a positive influence $(\beta=.241)$. Therefore, since the $p$-value is less than 0.05 the researcher supported the proposed hypothesis-i.e. Employee participation in the work place has a significant relation with employee's performance. 
Hypothesis 2: Openes to communication has a significant influence on employee's performance

Null hypothesis: Ho: $r=0$

Alternative hypothesis: $\mathrm{H} 1: \mathrm{r} \neq 0$

As indicated in the regression table, the $p$-value for Openness to communication was $(p=0.002)$ and the corresponding beta coefficient indicated a negative influence $(\beta=-.150)$. Therefore, since the $p$-value is less than 0.05 the researcher supported the proposed hypothesis-i.e. Openes to communication has a significant influence on employee's performance

Hypothesis 3: Risk taking and inovation capability of employee's has a significant relation with employee's performance.

Null hypothesis: Ho: $\mathrm{r}=0$

Alternative hypothesis: $\mathrm{H} 1: \mathrm{r} \neq 0$

As indicated in the regression table, the $\mathrm{p}$-value for risk taking and innovation was $(\mathrm{p}=0.002)$ and the corresponding beta coefficient indicated a positive influence $(\beta=.161)$.

Therefore, since the p-value is less than 0.05 the researcher supported the proposed hypothesis-i.e. : Risk taking and innovation capability of employee's has a significant relation with employee's performance

Hypothesis4: The reward system of the organization has a significant influence on employee's performance

Null hypothesis: Ho: $\mathrm{r}=0$

Alternative hypothesis: $\mathrm{H} 1: \mathrm{r} \neq 0$

As indicated in the regression table, the $p$-value for reward system was $(p=0.021)$ and the corresponding beta coefficient indicated a positive influence $(\beta=.103)$. Therefore, since the p-value is less than 0.05 the researcher supported the proposed hypothesis-i.e. The reward system of the organization has a significant influence on employee's performance.

Hypothesis5: Employee's customer service orientation in the work place has a significant influence on employee's performance

Null hypothesis: Ho: $r=0$

Alternative hypothesis: $\mathrm{H} 1: \mathrm{r} \neq 0$

As indicated in the regression table, the $\mathrm{p}$-value for customer service orientation was $(\mathrm{p}=0.038)$ and the corresponding beta coefficient indicated a positive influence $(\beta=0.111)$. Therefore, since the $p$-value is less than 0.05 the researcher supported the proposed hypothesis-i.e. Employee's customer service orientation in the work place has a significant influence on employee's performance

Hypothesis6: Employee's experience on the work place has a significant influence on employee's performance

Null hypothesis: Ho: $\mathrm{r}=0$

Alternative hypothesis: $\mathrm{H} 1: \mathrm{r} \neq 0$

As indicated in the regression table, the $p$-value for experience was $(p=0.209)$ and the corresponding beta coefficient indicated a positive influence $(\beta=0.048)$. Therefore, since the $p$-value is more than 0.05 the researcher unable to supported the proposed hypothesis. As a result the evidence indicate that the proposed hypothesis was rejected and supported alterantive hypothesis -i.e. Employee's customer service orientation in the work place has not significant influence on employee's performance

Hypothesis7: Employee's level of education has a significant influence on employee's performance

Null hypothesis: Ho: $r=0$

Alternative hypothesis: $\mathrm{H} 1: \mathrm{r} \neq 0$

As indicated in the regression table, the $p$-value for Employee's level of education was $(p=0.482)$ and the corresponding beta coefficient indicated a negative influence $(\beta=-0.006)$. Therefore, since the $p$-value is more than 0.05 the researcher unable to supported the proposed hypothesis. As a result the evidence indicate that the proposed hypothesis was rejected and alterantive hypothesis was supported -i.e. Employee's level of education has not significant influence on employee's performance.

\section{Summary of Finding, Conclusion and Recommendation}

This chapter presents a summary of the study findings and results of the study. Then based on the key findings and results, conclusions are drawn and recommendations made. The recommendations include interventions to improve employee"s performance in public service organization of Dire Dawa adminstration and pave the way for further studies.

\subsection{Summary of Major Findings}

This section presents summary of key findings of the study. The main objective of this research was to investigate the relationship between organizational culture and employee"s performance.The study cohort was 293 employees of public service organizattions of DireDawa adminstration. A questionnaire was used as data collection method. Then data was analyzed using the descriptive (mean and standard deviation) and inferential statistics (multiple regression) employed using SPSS20. 
In this study the $\mathrm{R}$ square value of the regression model is 0.779 . This indicates that $77.9 \%$ of the variance in employees job performance is explained by the model. The remaining $\left(1-\mathrm{R}^{2}\right)=22.1$ percent of the variance in employees job performance are explained by other variables which are not included in this model. According to Morgan et al (2007) this is a large effect.

The ANOVA table indicate that the combination of components of organizational culture variables to predict employees job performance from reward system, openness to communication, risk taking \& innovation, customer service orientation, employee participation, experience and education is statistically significant, $\mathrm{F}(5,287)=5.830$, $\mathrm{p}<0.000$ because as Morgan et.al (2007) pointed out that if the significance value of the F statistics is smaller than 0.05 then the combination of independent variables is good predictor of dependent variables.

Based on the result of regression analysis, exept experience and education all variables of organizational culture significantly predicting employee performance particularly from the above regression model employee participation and risk taking and innovation are most significantly predicting employee performance followed by openness to communication, customer service orientation and reward system. Because the two variables have larger coefficient value as compared to other variables.

However, the result of this study shows that employee experience and level of education have no association with employee performance. According to the result shows employee experience and level of education have not statistically significant therefore this make $\mathrm{p}>0.05$ This indicates that experience and level of education have no effect on employees performance.

Thereafter, multiple regressions indicate that not all variables of orgabizational culture predicted significant relationship to employee performance. Employee participation and risk taking and innovation were the most significant predictor of employee performance among public service employees of Dire Dawa adminstration followed by openness to communication, customer service orientation and reward system.

In order to measure the significant influence of independent variables on the dependent variable and to test the proposed hypotheses the researcher employed multiple regression analysis. Summary of an overview results of hypothesis testing given in the following table.

\begin{tabular}{|l|l|l|}
\hline \multicolumn{1}{|c|}{ Hypothesis } & result & reason \\
\hline $\begin{array}{l}\text { Hypothesis 1: Employee participation in the work place has a significant relation with } \\
\text { employee's performance. }\end{array}$ & supported & $\mathrm{P}<0.05$ \\
\hline $\begin{array}{l}\text { Hypothesis 2: Openes to communication has a significant influence on employee's } \\
\text { performance }\end{array}$ & supported & $\mathrm{P}<0.05$ \\
\hline $\begin{array}{l}\text { Hypothesis 3: Risk taking and inovation capability of employee's has a significant } \\
\text { relation with employee's performance. }\end{array}$ & supported & $\mathrm{P}<0.05$ \\
\hline $\begin{array}{l}\text { Hypothesis4: The reward system of the organization has a significant influence on } \\
\text { employee's performance }\end{array}$ & supported & $\mathrm{P}<0.05$ \\
\hline $\begin{array}{l}\text { Hypothesis5: Employee's customer service orientation in the work place has a } \\
\text { significant influence on employee's performance }\end{array}$ & supported & $\mathrm{P}<0.05$ \\
\hline $\begin{array}{l}\text { Hypothesis6: Employee's experience on the work place has a significant influence on } \\
\text { employee's performance }\end{array}$ & rejected & $\mathrm{p}>0.05$ \\
\hline $\begin{array}{l}\text { Hypothesis7: Employee's level of education has a significant influence on employee's } \\
\text { performance }\end{array}$ & rejected & $\mathrm{p}>0.05$ \\
\hline
\end{tabular}

the result of the above hypothesis test shows that there were strong link between organizational culture and employee's job performance within public service organizations of Dire Dawa adminstation.

\subsection{CONCLUSIONS:}

In this study, the researcher tries to evaluate the overall impact of organizational culture on the employee's job performance with the indication from public service organizations of Dire Dawa adminstration.

The preliminary research question investigated the affiliation between seven possible aspects of organizational culture, i.e. customer service, employee participation, reward system, innovation \& risk-taking, communication system,experiance and education. The results show that except communication system and level of education, all variables of organizational culture have positive relationship with employee's job performance at public service organizations of Dire Dawa adminstration.

Thereafter, multiple regressions indicate that not all variables of orgabizational culture predicted significant relationship to employee performance. Employee participation and risk taking and innovation were the most significant predictor of employee performance among public service employees of Dire Dawa adminstration followed by openness to communication, customer service orientation and reward system.

However, the result of this study shows that employee experience and level of education have no association with employee performance. According to the result shows employee experience and level of education have not statistically significant therefore this make $\mathrm{p}>0.05$ This indicates that experience and level of education have no effect on employees performance. 
the result of hypothesis test shows that there were strong link between organizational culture and employee's job performance within public service organizations of Dire Dawa adminstation.

Strong culture within the organization leads to raise the employee's commitment towards achieving the goals of the organization with a common path. It is very helpful to increase the performance of the employees. Personal beliefs are different from the organizational values when an employee is entering in the organization. In strong culture employees are on the common path towards achieving organizational goals, which also provide the opportunity to the employees to grow in the organization (Deal and Kennedy, 1982). It is found by results that employee's commitment and participation as well as recognition given for innovative idea are most important factors to increase the employee performance.

\subsection{Recommendation}

Basing on the findings from the study, the discussion that followed and the conclusions drawn in line with the study objectives, the following points are recommended.

$>$ Among the variables of organizational culture, employee paticipation and innovation considered by the employees as the main sources for their performance. Thus, public service organization of dire dawa adminstration should emphasize more on these variables to increase employees job performance.

> Openness to communiction also negativelly contributed to overall employee performance. Thus, public service organization of Dire Dawa adminstration should develop a system that employees have effective communication with their supervisors, because employees without effective communication cannot be empowered to act with responsibility. however, when the communication platform increase, it was significantlly affect employee performance. Thus, to improve employee performance public service organization of Dire Dawa adminstration should be minimized communication platform to amplify employees job performance.

$>$ Reward system is also considered as another source for employees performance improvement. Thus, to increase employees performance, public service organization of Dire Dawa adminstration should encourage, measure and reward employees based on their excellent and strong service performances that motivate individual or group of employees to become best performer and able to provide high quality service. public service organization of Dire Dawa adminstration should develop reward programs including pay-for-performance, compensation, bonus and any other mechanizem of motivating employees to improve performance.

$>$ Employees experience and their level of education is not significantly contributed to overall employee performance. Thus, public service organization of Dire Dawa adminstration should not be focused on the above two variables to improve employee job performance. This was mainly due to the fact that when their level of education and their experience increase, their salary and benefit were not inline with their expectation. Thus, public service organizations should not be focused on experience and level of education unless Dire Dawa adminstration design a new benefit package for public service employees in considering experience and level of education.

$>$ In order to improve or establish an effective employee performance management system in public service organization of Dire Dawa adminstration, it is advisable to carry out detailed cultural survey to identify the values, beliefs and assumptions. To do so, Dire Dawa adminstration are recommended to give concern for the research and development department; allocate enough resources such as material, fiancé and assign qualified experts.

$>$ It is imperative for the organization to revise rules, regulations and procedures that enable members to use their potential, and be creative, innovative, and effective for the successful implementation of employee performance management system. Since some working rules and procedures are rigid barriers for new ideas or innovations, public service organizations should identify critically those obstacles and propose effective and efficient working methods.

$>$ Improving employee performance through enhancement of organisational culture is hard, long and complex process that needs the commitment, support and understanding of all parties involved. Both management and employees share the responsibility for making it work. Hence, the influence of organizational culture on employee performance should be introduced gradually in order to fully integrate into the working environment. It should not be viewed as magical pill that can cure all problems in public service organization of Dire Dawa adminstration at once; it needs a long fostering period before one can pick its fruit.

\subsection{Limitations and Further Research}

5.4.1.Limitation of the study

As with all studies, this thesis is not free from limitations. Therefore, it is important to acknowledge factors which may have impacted the reliability and validity of the finding of the study. 
[1] Firstly, the method of data collection was relying purely on questionnaire which is deemed to be suitable for the analysis. However, the researcher would have to combine the use of interviews to gain further insight into the concepts of organizational culture and contextual performance from various employees. The researcher omitted open ended questions from the survey as this would have been far more difficult to analyze using statistical programs. Hence, the interviews would have given the researcher more information. Having said this it is important to note that interviews have their negative effects as well. One major negative effect is the difficulty of analyzing them and the greater danger of biases that come with the interviews. Thus, the researcher can say that by keeping the data purely quantitative the researcher have minimized the risk of such an event.

[D] Secondly, the researcher agrees that organizational culture and employee performance is complex and very wide topic. However, the current study limits itself on the independent variables such as: customer service, communication, employee participation, risk taking and innovation, reward system, employee experience and level of education. But there are other variables which are not incorporated in this study and might have an influence on employee performance. The research could have been more comprehensive if it had included variables other than those mentioned above.

\section{REFRENCES}

1. Argyrous George 2005 statistics for research: with guide to SPSS 2ed edition, London sage publication

2. Njugi Anne wanjiku (2014 ). Effect of Organization Culture on Employee Performance in Non Govermental Organizations international Journal of Scientific and Research Publications, Volume 4, Issue 11

3. Berrio, A. (2003). An Organizational Culture Assessment Using the Competing Values Framework: A Profile of Ohio State University Extension. Journal of Agricultural Education, 41(2).

4. Cameron, K. S., and Quinn, R. E. (1999). Diagnosing and changing organizational culture.Sydney AddisonWesley.

5. Daft, R. L. (2000). Organization Theory and Design. (7th Ed.) South-Western College Publishing, Thomson Learning. U.S.A.

6. Deal, T. E.,\& Kennedy, A. (1982). Corporate Culture: The Rites and Rituals of Corporate Life. Reading: M.A: Addison Wesley

7. Denison, D. R. (1990). Corporate Culture and Organizational Effectiveness. New York John Wiley and Sons.

8. Gamble, P. R.,\& Gibson, D. A. (1999). Executive values and decision-making: The relationship of culture and information flows. Journal of Management Studies, 36, 217-240.

9. Giszpenc, N. (2003). Human resources and Company Performance. The ESOP report, published by The ESOP Association.

10. Glisson, C., and James, R. L. (2002). The Cross Level Effects of Culture and climate inHuman Service Teams. Journal of Organizational Behavior 23(6)

11. Greenberg, and Baron, R. (1995). Behavior in Organization. New Jersey Prentice Hall.

12. Hofsrede, G. (1980). Culture's consequences International differences in work-related values. Newbury Park SAGE Publications.

13. Hofstede, G. (1991). Cultures and Organizations. Software of the Mind. London: McGraw-Hill

14. Juechter, M.W., Fisher, C. and Alford, R.J. (1998). Five Conditions for high performance cultures. Training and Development Magazine.

15. Joel and Michelle, L. (2000). Reflection for Leaders Corporate Culture, Organizational Health, and Human Potential. Journal of Employee Assistance Professional Association Exchange.

16. Kotter, J. P., and Heskett, J. L. (1992). Corporate Culture and performance. Macmillan, New York The Free Press.

17. Kopelman, R E., Brief, A. P. and Guzzo, R A. (1990). The role of climate and culture in productivity. San Francisco Jossey-Bass.

18. Kunda, G. (1992). Engineering culture Control and commitment in a high-tech corporation. Philadelphia Temple University Press.

19. Likert, R. (1967). The Human Organization Its Management and Value. New York McGraw- Hill.

20. Luthans, F. (1998). Organizational Behavior. New York Irwin/McGraw Hill.

21. Mallak, L. A. (1993). The development and application of a procedure to measure culture strength in organizations. Michigan A \& Howell Company.

22. Martin, J. (1992). Cultures in organizations three perspectives. New York Oxford University Press.

23. Moorhead and Griffin. (1995). Organizational Behavior Managing People and Organization. New Jersey Houghton Mifflin Company.

24. O'Reilly III, C. A., et al. (1991). People and organizational culture: A profile comparison approach to assessing person organization fit. Academy of Management Journal, 34, 487-516.

25. Pertes, T. and Waterman, R. J. (1982). In Search of Excellence Lessons from America's Best-run Companies. 
New York Warner Books.

26. Pfeiffer J. (1998). The Human Equation Building Profits by Putting People First. Boston Harvard Business School Press.

27. Ricardo, R.,\& Wade, D. (2001). Corporate Performance Management: How to Build a Better Organization Through Measurement Driven Strategies Alignment. Butterworth Heinemann.

28. Robbins, Stephen, and Mary. (1996). Management. New Jersey Prentice Hall.

29. Schein, E. H. (1990). Organizational Culture. American Psychologist, 43 (2), 109-119.

30. Schein, E. H. (1992). Organizational Culture and Leadership. San Francisco Jossey-Bass.

31. Sheridan, J. E. (1992). Organizational culture and employee retention. Academy of Management Journal, 35, 1036-1056.

32. Stewart D. (2010). Growing the Corporate Culture. Obtained from https://www.wachovia.com/foundation/v/index.jsp?vgnextoid=ab411f07760aa110VgnV CM1000004b0d1872RCRD\&vgnextfmt=default.

33. Wilkins, A. L., and Ouchi, W. G. (1983). Efficient cultures exploring the relationship between culture and organizational performance. Administrative Science Quarterly, Vol. 28, 1983. pp.

34. Fakhar Shahzad, Zahid Iqbal and Muhammad Gulzar (2013). Impact of Organizational Culture on Employees Job Performance: An Empirical Study of Software Houses in Pakistan. Journal of Business Studies Quarterly, Vol. 5 NO. 2

35. Zairi, M. (1999). Best Practices Process Innovation Management. Jordan Hill Oxford Butterworth Heinema

36. Hofstede, G. (2007). Culture's Consequences: International Differences in Work Related Values. Beverly Hills, CA: Sage Publications.

37. Kotter, J. P (2012). Corporate Culture and performance. New York: Free Press.

38. Magee, K. (2002). Relationship between Organizational Culture and Performance Management in Pakistan University. Journal of Competitiveness, 5(1) 67-71.

39. Azhar, K. (2003). Business Policy and Strategic Management, New Delhi: Tata McGraw-Hill.

40. Racelis, A. D (2010). The influence of organizational culture on performance of Philipine Banks. Social Science Dilman, 6(2) 29-49.

41. Selltiz, et.al, (1962), "Consumer Attitudes Towards Foreign Cars”, International Business Studies II (Spring), pp.71- 80 .

42. Creswell, (2008), Research design: Qualitative, quantitative and mixed methods approaches (3rd ed.). Thousand Oaks, CA: Sage.

43. Kate Le Gallez(2018), What is employee experience? Journal of culture IQ. Retrieved from https://blog.cultureamp.com

44. Natalie Smith(2018), Essential to Invest in Employee Education. Journal of culture IQ. Retrieved from rhttps://cultureiq.com

45. Morgan et.al. 2007, SPSS for introductory statistics; use and interpretation $3^{\text {rd }}$ edition. Lawrence association publication 